\title{
DESIGN OF A GRID CONNECTED SOLAR SYSTEM FOR YOLA NORTH AND SOUTH, ADAMAWA STATE
}

\author{
Engr. Alfred, Ba'amani Baams \\ Department of Electrical \& \\ Electronics Engineering, \\ Modibbo Adama University of \\ Technology, Yola, Nigeria
}

\author{
Engr. Dr. Iliya Tizhe Thuku \\ Department of Electrical \& \\ Electronics Engineering, \\ Modibbo Adama University of \\ Technology, Yola, Nigeria
}

\author{
Engr. Simon Samuel \\ Department of Electrical\& \\ Electronics Engineering, \\ Modibbo Adama University \\ of Technology Yola,Nigeria.
}

\begin{abstract}
In this research work, a grid connected solar photovoltaic (PV)-battery energy storage system (PV/BESS) was designed to improve the power supply of Yola north and south. The solar photovoltaic panel model adopted is $100 \mathrm{~W}$ monocrystalline photovoltaic panel, and the average solar radiation of the study area is $654.40 \mathrm{~W} / \mathrm{m}^{2}$. The system consists of modeled PV Array, Boost converter model, three-phase power inverter model, step-up power transformer and modeled Phase locked loop. The designed solar photovoltaic model generated 3.40MW of electric power via the step-up transformer, which was integrated into the utility grid of the study area. The output signal of the solar PV array was optimized using boost converter. The inverter inverted the output of the PV array to AC signal, which is connected to step-up power transformer to step-up the three-phase AC voltages to the grid voltages level. PLL was designed for proper synchronization of the solar PV model with the grid without harmonic distortions. The designed solar PV array model was able to supplement the deficit power of $3.40 \mathrm{MW}$ to the grid of the study area.
\end{abstract}

Keywords: Photovoltaic System, Boost Converter, 3-phase power Inverter, PLL, step-up power transformer and grid source.

\section{INTRODUCTION}

This paper focuses on the design and simulation of a grid connected PV system that will augment the shortfall in power supply in Yola North and South as well as to overcome the problem of load shedding. The increase of the study area energy demand, due to modern industrial development, population growth and global warming, encourages investments in renewable energy. Hence, alternative energy in particular solar energy serves as solution to the inadequate power supply of the study area. However, battery energy storage system (BESS) is connected to the systems for use at night and during cloudy days. The solar power system used photovoltaic (PV) cell to convert solar radiation to electricity [20]. The PV cell produces only a small amount of current and voltage. So, in order to meet a large load demand, the photovoltaic cell has to be connected into modules and the modules connected into arrays [1]. The grid connected solar photovoltaic system is designed in cognizance of the effect of environmental weather conditions. The PV array model output signal connected to the utility network is converted to AC signals compatible with the grid AC voltage. This paper discusses the detailed modeling and simulation of the complete grid-connected PV array system. The solar PV array model is connected to the utility grid by a DC-DC boost converter that boosted the PV array model output voltage, and DC-AC inverter inverted the DC output voltage of the PV array into the three-phase AC voltages. The PI control circuit of the DC-converter was used to maintain constant DC input of the inverter. The model of the entire system is simulated in Matlab/Simulink environment. The block diagram of the design is shown in Figure 1. It consists of photovoltaic Array, DC-DC boost converter, BESS, 3-phase Inverter, 3-phase PLL, 3- phase step-up transformer, 3-phase load and 3-phase utility grid source.

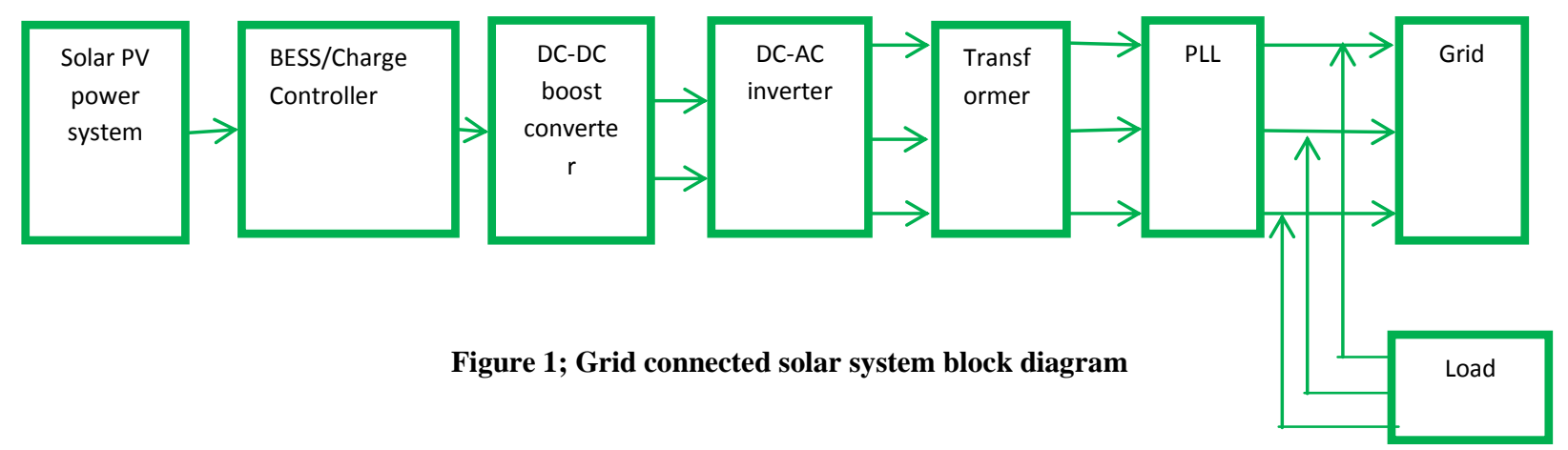




\section{System design}

This section deals with the modeling and simulation of the complete designed of grid connected solar PV array that formed the sub-systems. The following steps were considered for the actualization of the design; Data collected on load demand and weather conditions of the study area from YEDC, TCN and NAMA Yola, design and simulation of solar PV array system in Matlab/Simulink programs and synchronization in order to control the disturbances on the lines.

\section{Solar array sizing}

The power of one module is not enough to meet the power requirement of the study area. Some of the modules in a PV array are connected in series to obtain the desired voltage while some are connected in parallel to produce current that made up the required power [9]. However, diodes are connected alongside the photovoltaic cells to avoid reverse currents, in case of partial or total shading [13]. The total number of photovoltaic (PV) modules required for the grid connected solar system for the study area is calculated using the equations given as follows;

$$
\begin{aligned}
& E_{\mathrm{r}}=\frac{\frac{\text { Daily averageconsumption }}{\text { demand }}}{\text { product of components efficiency }} \\
& E_{Y}=\frac{E}{\mathrm{r}_{\text {averali }}}
\end{aligned}
$$

Where;

$\mathrm{E}_{\mathrm{r}}=$ Require energy

$\mathrm{E}=$ Daily energy or demand in Watt-hours $\eta=$ Component efficiency

The peak power $\left(\mathrm{P}_{\mathrm{p}}\right)$ is equal to the required energy $\left(\mathrm{E}_{\mathrm{r}}\right)$ divided by the average sun hours $\left(\mathrm{T}_{\min }\right)$ per day for a particular geographical location [2]. The equation 2 computes the $\mathrm{P}_{\mathrm{p}}$.

$P_{p}=\frac{\text { Daily Energy requirement }}{\text { minimum sun peak hours per day }}$

$P_{p}=\frac{E_{r}}{T_{\min }}$

Where;

$\mathrm{E}_{\mathrm{r}}=$ Require energy

$\mathrm{P}_{\mathrm{p}}=$ peak power

$\mathrm{T}_{\min }=$ period

The total direct current ( $\mathrm{I}_{\mathrm{dc}}$ measure in Amp) of the photovoltaic module is given by equation 3

$I_{d e}=\frac{\text { peak power }}{\text { system DC Voltage }}=\frac{P_{p}}{V_{d e}}$

Where;

$\mathrm{I}_{\mathrm{dc}}=$ total dc current

$\mathrm{P}_{\mathrm{p}}=$ Peak power

$\mathrm{V}_{\mathrm{dc}}=$ DC-voltage

The mathematical expression of modules connected in series $\left(\mathrm{N}_{\mathrm{s}}\right)$ and parallel $\left(\mathrm{N}_{\mathrm{p}}\right)$ for the production of the current and voltage obtain the power demand of the study area are presented in equations 4 and 5 .

$$
\begin{aligned}
& N_{s}=\frac{\text { system DC Voltage }}{\text { One module Rated Voltage }}=\frac{V_{\text {de }}}{V_{r}} \\
& N_{p}=\frac{\text { Whole Module current }}{\text { Rated current of one module }}=\frac{I_{\text {de }}}{I_{r}}
\end{aligned}
$$$$
\text { [16] }
$$$$
\text { Where; }
$$

$\mathrm{N}_{\mathrm{s}}=$ Number of modules in series

$\mathrm{N}_{\mathrm{p}}=$ Number of modules in parallel

$\mathrm{V}_{\mathrm{r}}$ : = Rated voltage of each module

$\mathrm{I}_{\mathrm{r}}=$ Rated current of a single module

$\mathrm{I}_{\mathrm{dc}}=$ Whole DC current

The total number of photovoltaic modules needed for the power requirement of the study area is calculated using equation 6 .

$$
N_{m}=N_{S} \times N_{P}
$$

$\mathrm{P}_{\mathrm{P}}$ of $3.40 \mathrm{MW}$ and $\mathrm{V}_{\mathrm{dc}}$ of the system $4000 \mathrm{~V}$

The total dc current $\left(\mathrm{I}_{\mathrm{dc}}\right)$ is calculated using the equation 3 to give;

$$
\begin{aligned}
& I_{\mathrm{dc}}=\frac{\text { peak power }}{\text { System DC Voltage }}=\frac{\mathrm{P}_{\mathrm{p}}}{\mathrm{V}_{\mathrm{dc}}} \\
& \mathrm{I}_{\mathrm{dc}}=\frac{3.40 \mathrm{MW}}{4000 \mathrm{~V}}=850 \mathrm{~A}
\end{aligned}
$$

To determine the number of PV modules in series $\left(\mathrm{N}_{\mathrm{s}}\right)$ the equation 4 is used;

$$
\begin{aligned}
& N_{s}=\frac{\text { system DC Voltage }}{\text { One module Rated Voltage }} \\
& N_{s}=\frac{V_{d c}}{V_{T}}=\frac{4000 \mathrm{~V}}{17.40 \mathrm{~V}}=230 \text { modules. }
\end{aligned}
$$

Calculation of number of modules in parallel using equation 5 is shown as Follow;

$$
\begin{aligned}
& N_{p}=\frac{\text { Whole Module current }}{\text { Rated current of one module }} \\
& N_{p}=\frac{I_{\text {de }}}{I_{r}}=\frac{850 \mathrm{~A}}{5.75 \mathrm{~A}}=148 \text { modules. }
\end{aligned}
$$

The total number of modules required for the complete design of the system is calculated using equation 6 as follows:-

$N_{m}=N_{s} \times N_{p}=230 * 148=$
34,040 Modules

\section{PV System Modeling}

Photovoltaic module has standard mathematical modeling equations [12]. These equations are used in modeling and 
simulation of the system using matlab-simulink program. The characteristic equations of solar photovoltaic cell are applied in the formation of the photovoltaic arrays. These characteristic equations of the PV cell are given as;

\section{i. Reverse saturation current $\left(I_{r r}\right)$ equation;}

$$
I_{r T}=\frac{I_{S C r}}{\exp \left({ }_{S_{G} K A T_{T k}}-1\right)}
$$

Where;

$\mathrm{I}_{\mathrm{scr}}=$ Short Circuit Current $=6.32 \mathrm{~A}$,

$\mathrm{Q}=$ Electron charge $=1.6 \times 10^{-19} \mathrm{C}$,

$\mathrm{V}_{\mathrm{oc}}=$ Open circuit $\mathrm{V}$

Voltage $=21.60 \mathrm{~V}$

$\mathrm{N}_{\mathrm{s}}=$ Number of modules in series $=230$

$\mathrm{k}=$ Boltzmann's constant $=1.3805 \times 10^{-23} \mathrm{~J} / \mathrm{K}$,

$\mathrm{A}=$ Ideality factor of diode $=1.3$,

$\mathrm{T}_{\mathrm{rk}}=$ Reference temperature $=298.15 \mathrm{~K}$

\section{ii. Band gap of solar cell (EG) equation;}

$E_{G}=E_{G(0)}-\frac{\alpha\left(T_{o p}\right)^{2}}{T_{o p}+\beta}$

[17]

Where;

$\alpha=$ alpha $=0.473$

$\mathrm{Eg}(0)=1.166$

$\beta=$ beta $=636$

$\mathrm{T}_{\mathrm{op}}=$ operating temperature $=305.7 \mathrm{~K}$

iii. Reversed saturation current at $\mathbf{T}_{\mathrm{op}}\left(\mathbf{I}_{\mathrm{rs}}\right)$;

$I_{r s}=I_{r r}\left[\frac{T_{o p}}{T_{r k}}\right] * \operatorname{Exp}\left(\frac{Q E_{G}}{K A}\left[\frac{1}{T_{o p}}-\frac{1}{T_{r k}}\right]\right)$

Where;

$\mathrm{I}_{\mathrm{rr}}=$ Reverse saturation current

$\mathrm{T}_{\mathrm{op}}=$ operating temperature $=305.7 \mathrm{~K}$

$\mathrm{T}_{\mathrm{rk}}=$ Reference temperature $=298.15 \mathrm{~K}$

$\mathrm{Q}=$ Electron charge $=1.6 \times 10^{-19} \mathrm{C}$

$\mathrm{EG}=$ Band gap energy

$\mathrm{k}=$ Boltzmann's constant $=1.3805 \times 10^{-23} \mathrm{~J} / \mathrm{K}$

$\mathrm{A}=$ Ideality factor of diode $=1.3$

iv. Photo-current $\left(I_{\text {ph }}\right)$ equation;

$I_{p h}=\left[I_{s c r}+K_{i}\left(T_{o p}-T_{r k}\right)\right] * S$

Where;

$\mathrm{I}_{\mathrm{scr}}=$ Short circuit current $=6.32 \mathrm{~A}$

$\mathrm{Ki}=$ short-circuit current of cell at $=0.00023$

$\mathrm{T}_{\mathrm{op}}=$ operating temperature $=305.7 \mathrm{~K}$

$\mathrm{T}_{\mathrm{rk}}=$ Reference temperature $=298.15 \mathrm{~K}$

$\mathrm{S}=$ solar irradiation $(\mathrm{W} / \mathrm{m} 2)$ of the study area with average value $654.40 \mathrm{~W} / \mathrm{m} 2$

\section{v. Thermal Voltage $\left(V_{\text {th }}\right)$ equation;}

$$
V_{t h}=\frac{Q}{K T_{o p}}
$$

[4]

Where;

$\mathrm{Q}=$ Electron charge $=1.6 \times 10^{-19} \mathrm{C}$ $\mathrm{k}=$ Boltzmann's constant $=1.3805 \times 10^{-23} \mathrm{~J} / \mathrm{K}$

$\mathrm{T}_{\mathrm{op}}=$ operating temperature $=305.7 \mathrm{~K}$

\section{vi. Current source output (I) equation;}

$I=N p I_{P h}-N p I_{r s_{2}}\left[\exp \left(\frac{Q}{A k T} * \frac{V_{t h}}{N_{S}}\right)-1\right]$

Where;

$\mathrm{N}_{\mathrm{p}}=$ Number of modules in parallel $=148$

$\mathrm{I}_{\mathrm{ph}}=$ Photo-current

$\mathrm{I}_{\mathrm{rs}}=$ Reversed saturation current at $\mathrm{T}_{\mathrm{op}}$

$\mathrm{Q}=$ Electron charge $=1.6 \times 10^{-19} \mathrm{C}$

$\mathrm{k}=$ Boltzmann's constant $=1.3805 \times 10^{-23} \mathrm{~J} / \mathrm{K}$

$\mathrm{A}=$ Ideality factor of diode $=1.3$

$\mathrm{V}_{\mathrm{th}}=$ Thermal Voltage

$\mathrm{N}_{\mathrm{s}}=$ No. of modules in series $=230$

[14]

The mathematical equations of these components were modeled individually and networked together to determine the functionality of the PV array. Hence, these equations are important for the design of the PV array [5], because it determine the desired output of the system. The first step in photovoltaic system modeling is to know the PV array size, determined using equation 6 .

\section{Modeled solar PV array system.}

The modeling and simulation of the components of the photovoltaic system formed the masked subsystem of the PV array as shown in Figure 2. The subsystem of the PV array was simulated on a matlab-simulink environment. The result of the simulated solar PV array masked subsystem was satisfactory, and it serves as an input to the boost converter.

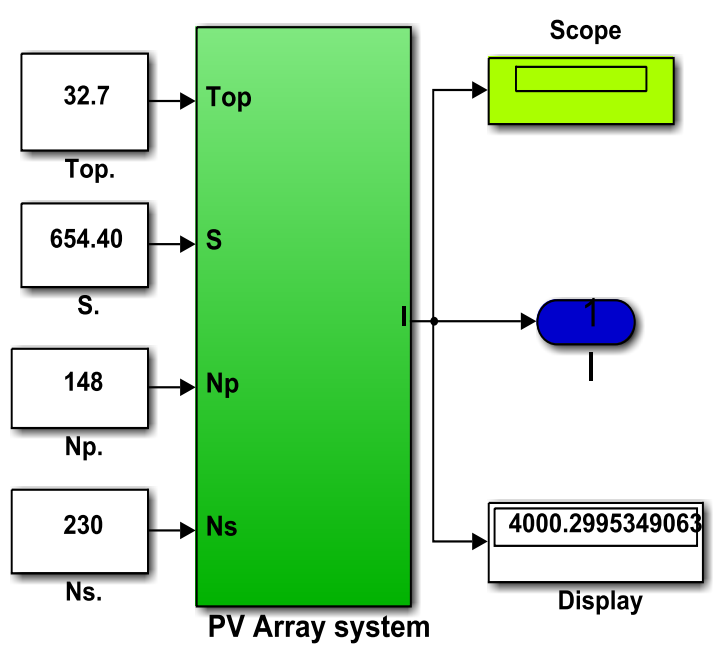

Figure 2; Modeled Photovoltaic (PV) array system

The internal structure of the masked subsystem of PV array of figure 2 such as figure 3, 4, 5, 6, 7 and 8 are given as follows;

\section{1; Reverse saturation current $\left(I_{\text {rr }}\right)$ model}




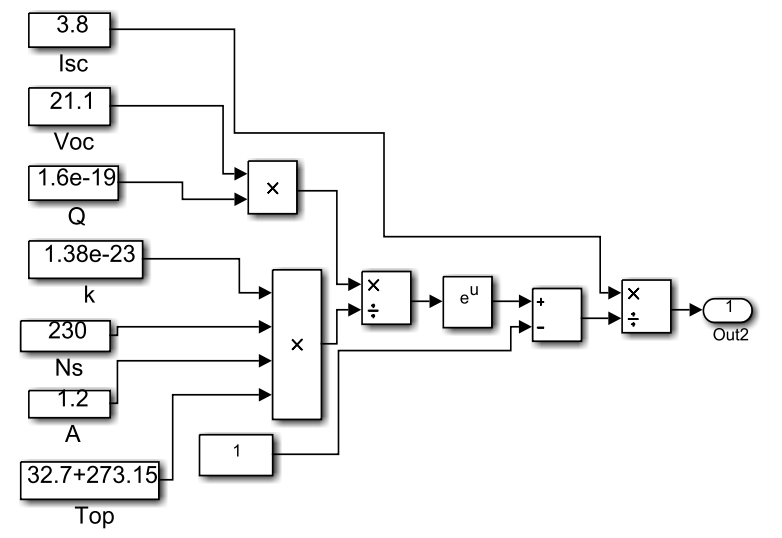

(a) Irr simulink blocks.

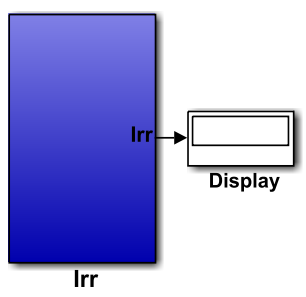

(b) Irr subsystem

Figure 3; (a) Reversed saturation current $\left(I_{r r}\right)$ Simulink Block and (b) $I_{r r}$ simulink block converted to $I_{r r}$ subsystem

\subsection{Band gap of the solar cell (EG) model}

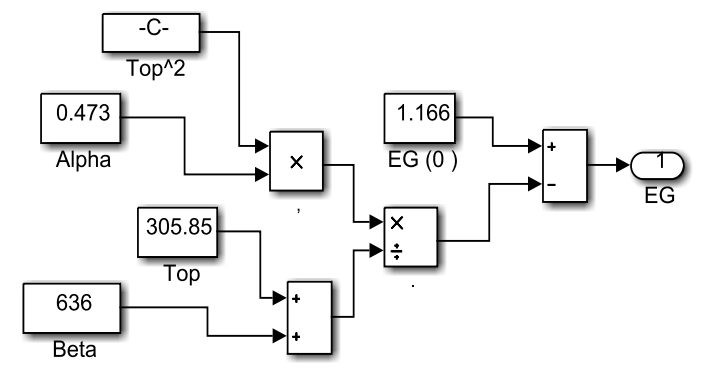

(a) EG simulink blocks.

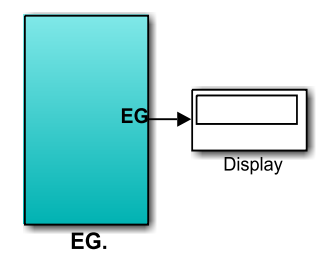

(b) EG subsystem

Figure 4; (a) Band gap of the solar cell (EG) Simulink block and (b) EG Simulink block converted to EG subsystem

\section{3; Reversed saturation current at $T_{\text {op }}\left(I_{r s}\right)$ model}

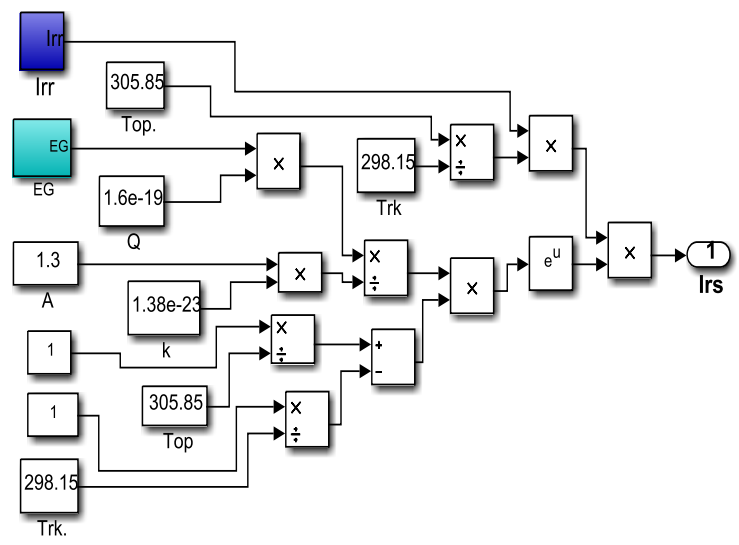

(a) Irs simulink blocks.

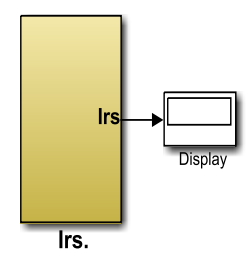

(b) Irs subsystem

Figure 5; (a) Reversed saturation current at $\mathbf{T}_{\mathrm{OP}}\left(\mathrm{I}_{\mathrm{rs}}\right)$ simulink block and (b) $I_{r s}$ simulink block converted to subsystem

\section{4; Photo-current $\left(I_{p h}\right)$ model}

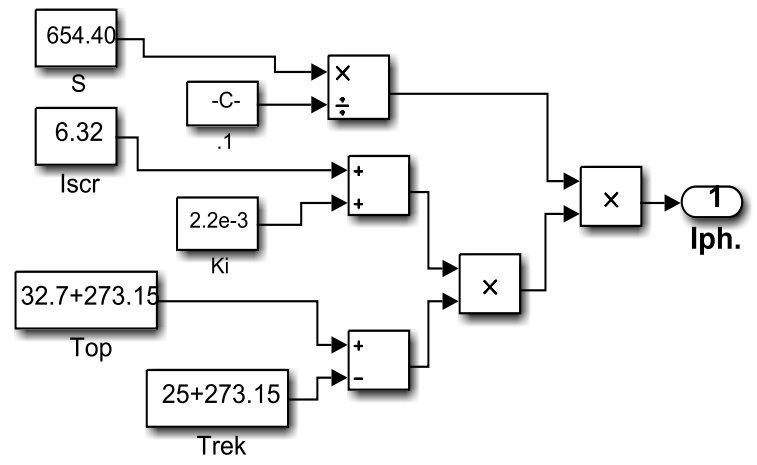

(a) Iph simulink blocks.

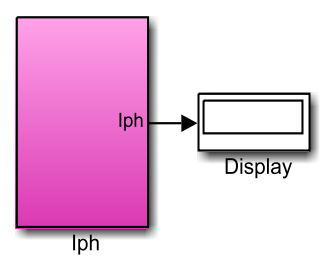

(b) Iph subsystem

Figure 6; (a) Photovoltaic Current $\left(I_{\mathrm{ph}}\right)$ Simulink Block and (b) $I_{p h}$ Simulink Block converted to subsystem

\section{5; Thermal voltage $(V)$ model}




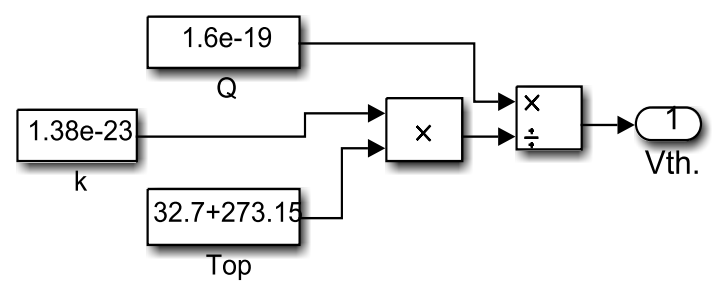

(a) Vth simulink blocks.

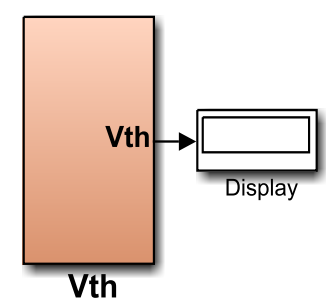

(b) Vth subsystem

Figure 7; (a) Thermal Voltage (V) Simulink Block and (b) V Simulink Block converted to subsystem.

\section{6; Current source output (I) model}

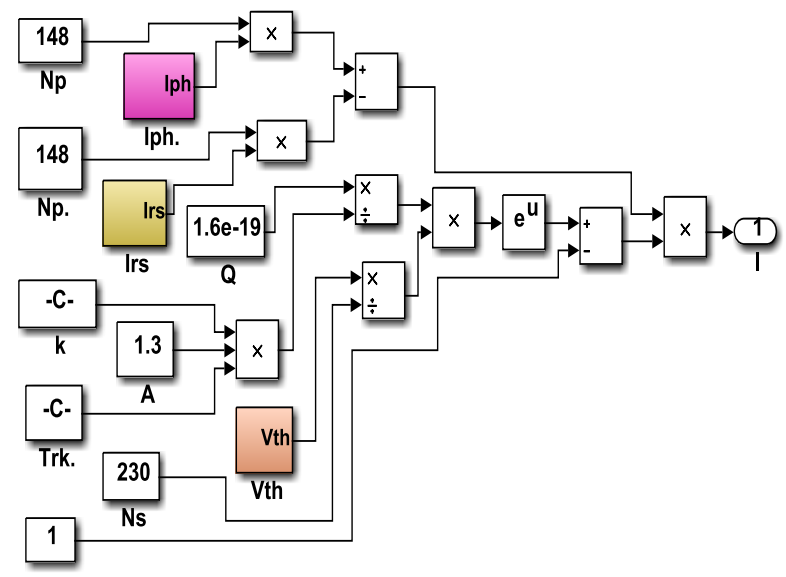

(a) I simulink blocks.

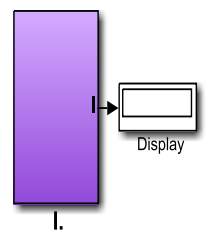

(b) I subsystem

Figure 8; (a) Current source output (I) simulink block and (b) I simulink block converted to subsystem.

\section{7; Design and modeling of the Boost Converter}

The boost converter is a system designed to converts low input signal (DC voltage) to high output signal (DC voltage). The unregulated input DC signal is filtered and then boosted to regulated output DC signal [7]. Here, the input DC source of the converter is PV output signal (DC voltage), which is boosted to a desired output of the converter. The design of boost converter is important, because it will help in controlling both the current (CRF) and voltage ripples(VEF ). CRF was selected as $10 \%$ and VRF was also selected as $5 \%$, in line with International Electro-technical Commission (IEC) harmonized standard which is bounded within the range 0$30 \%$ [12]. Where Switching Frequency $\left(\mathrm{f}_{\mathrm{s}}\right)=100 \mathrm{KHz}, \Delta \mathrm{Io} / \mathrm{Io}=10 \%$ and $\Delta V o / V o=5 \%$ are values for CRF and VRF used in the design to produce output with minimal ripples. The capacitor, inductor and the duty cycle are calculated using the given parameters of Input voltage $\left(\mathrm{V}_{\mathrm{g}}\right)$ and output voltage $\left(\mathrm{V}_{\mathrm{o}}\right)$ of the system converter where input and output voltage is $4000 \mathrm{~V}$ and $7400 \mathrm{~V}$.

$\mathrm{V}_{\mathrm{g}}=4000 \mathrm{~V}$,

$\mathrm{V}_{\mathrm{o}}=7400 \mathrm{~V}$

$\mathrm{I}_{\mathrm{o}}=275 \mathrm{~A}$

Calculation of the duty cycle (D):-

$$
\begin{aligned}
& V o / V g=1 /((1-D) \\
& 1 /((1-D))=V o / V g \\
& 1 /((1-D))=7262 / 4000=0.449 \\
& D=0.449 \quad \text { (duty cylce } D)
\end{aligned}
$$

Inductor (L) calculation:-

$$
\begin{aligned}
& \Delta I=(0.1 * 275) \mathrm{A}=27.5 \mathrm{~A} \\
& L=\frac{D V_{g}}{f_{s}\left(\Delta I_{L}\right)}=\frac{(4000 * 0.449)}{\left(275 * 100 * 10^{3}\right)}=\frac{1796}{27500000} \\
& L=0.0000653 \mathrm{H}=0.065 \mathrm{mH} \\
& R o=V o / I_{0}=7262 / 275=26.41=26.41 \Omega
\end{aligned}
$$

Calculation of the Capacitor (C) as follows:-

$\frac{\Delta V_{0}}{V_{o}}=\frac{D T_{S}}{C R_{0}} \quad$ where $C=\frac{D}{R_{o} f} * \frac{1}{\frac{\Delta V_{0}}{V_{0}}} \quad$ Therefore, capacitor is calculated as follows;

$$
\begin{aligned}
& C=\frac{0.449}{26.41 * 100 * 10^{3} * 0.05} \\
& C=3.4 \mu F
\end{aligned}
$$

The boost converter of figure 9 was modeled and simulated on Matlab-Simulink environment, which then boosted the input DC voltage to $7400 \mathrm{~V}$. However, the pulse width modulation controller and its duty cycle were used to turn and stabilize the converter output. Hence, figures 10 shows the PV array connected to boost converter model 


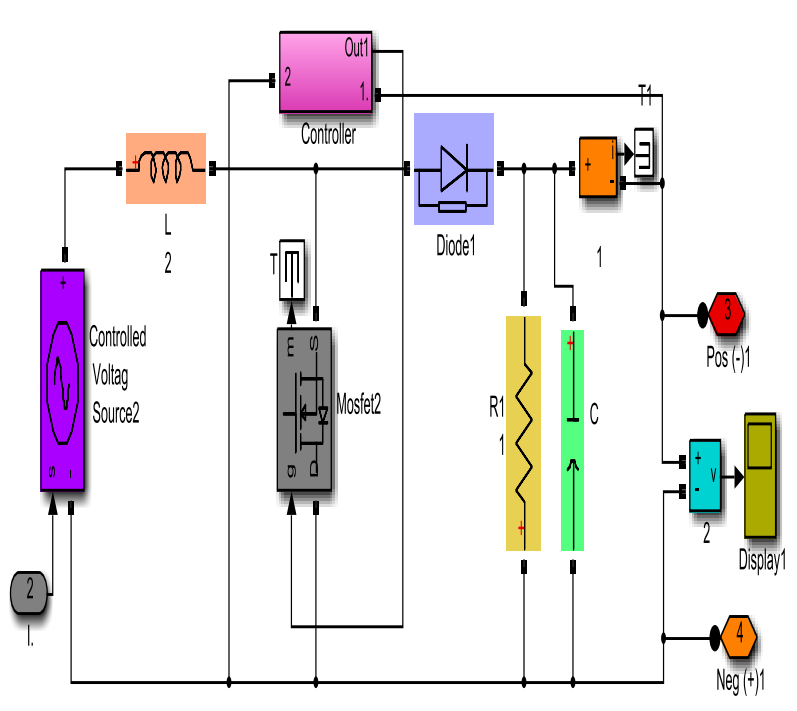

(b) DC.DC boosis converter Simulink block

Figure 9; Boost converter simulink block.

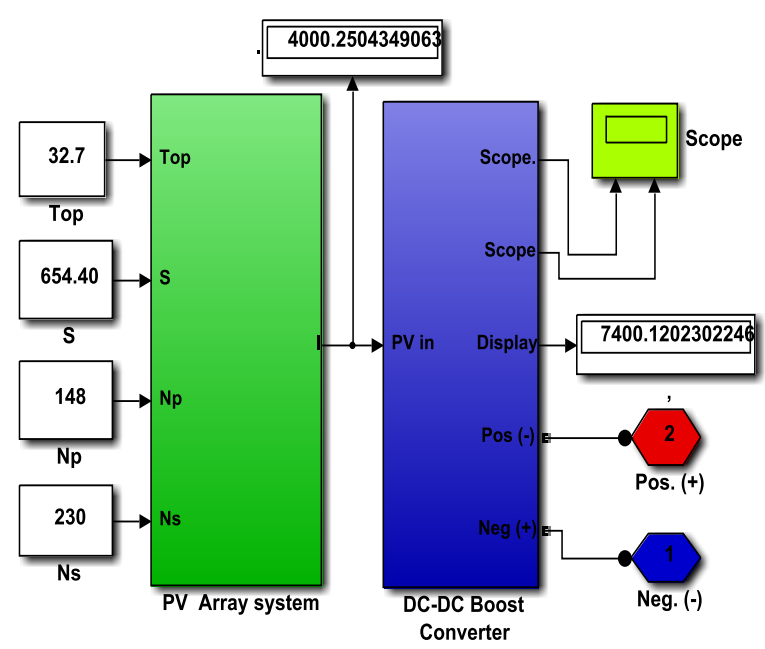

Figure 10; The interfaced of the PV array and boost converter model

\section{8; Design of Battery energy storage system (BESS)}

The battery storage system is the most efficient method of storing generated energy from solar PV system for use at night, cloudy, rainy and dusty days [18]. The BESS also maintaining power stability between the PV system and the utility grid [15]. In sizing the battery bank estimated energy storage is first determined [3]. The type of battery used is deep-cycle lead acid. The capacity of the entire battery bank is computed in ampere-hours, Electrical characteristics of the battery are given as; Number of Days of Autonomy $\left(\mathrm{D}_{\text {aut }}\right)=3$ Where

$\mathrm{E}_{\text {est }}=$ Estimated Energy Storage

$\mathrm{E}_{\text {safe }}(\mathrm{Wh})=$ Safe Energy Storage

$\mathrm{C}_{\mathrm{tb}}(\mathrm{Ah})=$ Total Capacity of Battery Bank

$\mathrm{N}_{\mathrm{tb}}=$ Total Number of Batteries in Bank

$\mathrm{N}_{\mathrm{sb}}=$ Number of Batteries in Series
$\mathrm{N}_{\mathrm{pb}}=$ Number of Batteries in Parallel

$\mathrm{C}_{\mathrm{b}}=250 \mathrm{Ah}$,

$\mathrm{V}_{\mathrm{b}}=12 \mathrm{~V}$,

$\mathrm{D}_{\text {disch }}=80 \%$

$E_{\text {est }}=E_{d} * D_{\text {aut }}$

$E_{\text {safe }}=\frac{E_{\text {est }}}{D_{\text {disch }}}$

$C_{t b}=\frac{E_{s a f e}}{V_{b}}$

$N_{t b}=\frac{c_{t b}}{C_{b}}$

$N_{s b}=\frac{V_{d c}}{V_{b}}$

$N_{p b}=\frac{N_{b}}{N_{s b}}$

[10]

$E_{\text {est }}=E_{d} * D_{\text {aut }}=3400000 * 3=$ $10200 \mathrm{Kwh}$

$$
\begin{gathered}
E_{\text {safe }}=\frac{E_{\text {est }}}{D_{\text {disch }}}=\frac{10200000}{80 \% 6}=12750 \mathrm{KWh} \\
C_{t b}=\frac{E_{\text {safe }}}{V_{b}}=\frac{12750000}{12}=1062.5 \mathrm{KAh} \\
N_{t b}=\frac{C_{t b}}{C_{b}}=\frac{1062500}{250}=4250 \text { Batteries }
\end{gathered}
$$

(Total Batteries required $=4250$ )

$N_{s b}=\frac{V_{d c}}{V_{b}}=\frac{4000}{12}=333.3$

(Number of Batteries in Series $=333.3$ )

$N_{p b}=\frac{N_{b}}{N_{s b}}=\frac{4250}{333.3}=12.8$

(Number of Batteries in parallel $=12.8$ )

\section{9; Charge controller (CC) design}

A battery charge controller (BCC) is a device that controls the power flow within the system and regulates the system voltage to a specified range. Its purpose is to keep batteries properly fed and safe for the long term [11]. The system also block reverse current and control battery overcharge [18]. The design of a suitable $\mathrm{CC}$ starts by computing the required total current that the controller should withstand. The properties of the selected CC are as follows:

$\mathrm{V}_{\mathrm{cc}}=24$,

$\mathrm{I}_{\mathrm{cc}}=60 \mathrm{~A}(\mathrm{dc})$,

Safety Factor $\left(\mathbf{F}_{\text {safe }}\right)=1.25$

The numbers of desired CC are calculated as follows; $\mathrm{N}_{\mathrm{ccn}}=$ Number of Charge Controllers

$\mathrm{I}_{\mathrm{rcc}}(\mathrm{A})=$ Required CC Current

$\mathrm{N}_{\mathrm{pm}}=$ Number of modules in parallel $=148$

$\mathrm{I}_{\mathrm{sc}} \mathrm{M}=$ Short circuit current of the selected module $=6.32 \mathrm{~A}$

$\mathrm{N}_{\mathrm{cc}}=$ Number of CC

$I_{\text {rce }}=I_{\text {ac }} M * N_{\text {pm }} * F_{\text {gafe }}$

$N_{\text {ce }}=\frac{I_{\text {rar }}}{I_{\text {ce }}}$

$I_{\text {rce }}=I_{\text {se }} M * N_{\text {pm }} * F_{\text {safe }}=6.32 * 148 * 1.25$

$l_{\text {rec }}=1169.2 \mathrm{~A}$

$N_{c e}=\frac{I_{r c e}}{I_{c c}}=\frac{1169.2}{60}=19.49=20$

Number of Charge Controllers required $=20$ 


\section{0; Power AC Inverter design}

All power generating plants that generate DC power normally need inverters to convert the power generated to $\mathrm{AC}$ power for use by AC rated appliances [11]. The subsystem of PV system-inverter shown in figure 11 is a complete block diagram of interfaced PV array model, DC converter and AC inverter model. The 3.phase AC output signals of the PV system-inverter model are the signals injected into the grid. The output of this model is a 3-phase sinusoidal signals module serves as an input to 3-phase step-up transformer to be connected to the grid system.

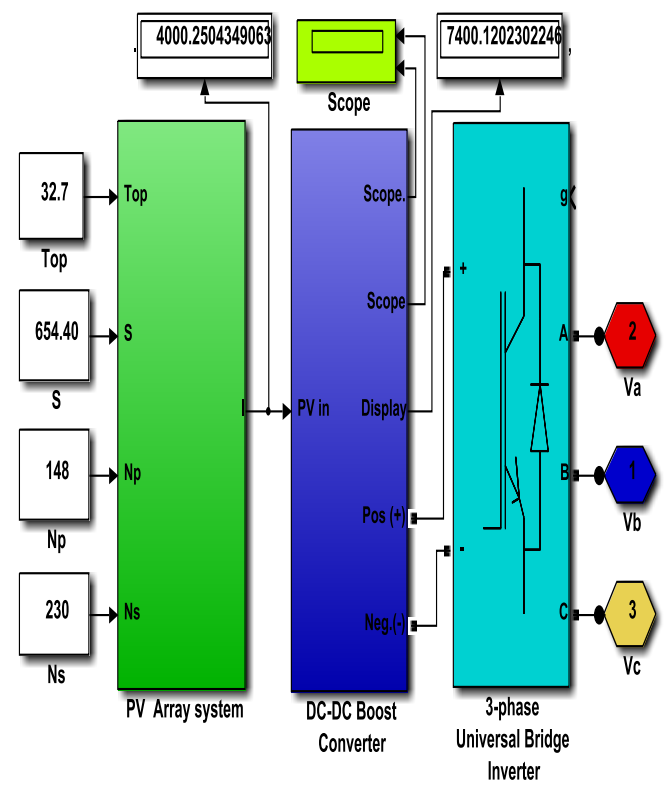

Figure 11; The block diagram of complete interfaced PV system with Booster and inverter.

\section{1; Phase locked loop (PLL) modeling}

The PLL is designed to control the phase difference and other harmonic distortion. The phase of generated signals of solar system is automatically adjusted to match the phase of an input signals of the grid. Figure 12 is the PLL Simulink block and as well an internal structure of figure 13. The model was simulated using Matlab/Simulink software.

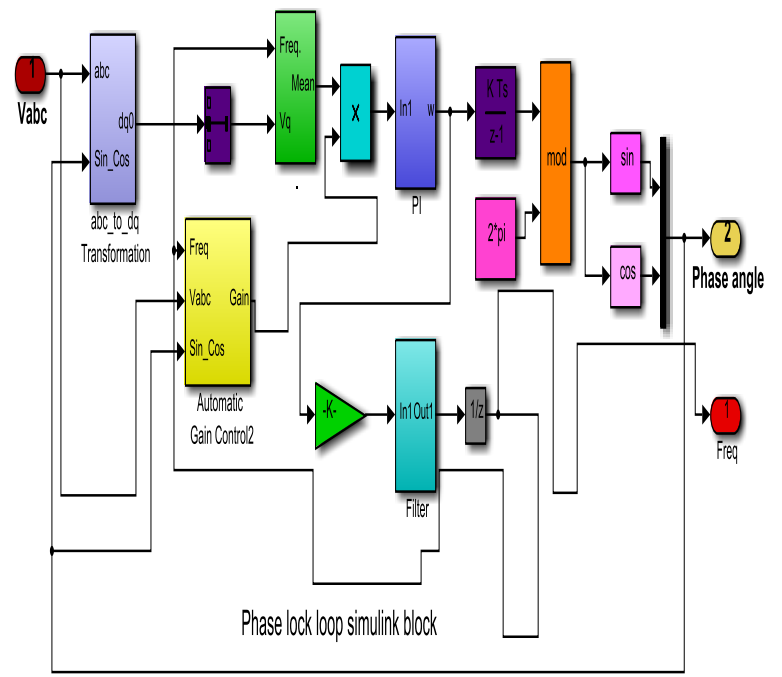

Figure 12; PLL Simulink block
The three blocks subsystem of PLL shown in figure 13 consists of the followings; phase detector (PD), loop filter (LF) and voltage controlled oscillator VCO. The PD is a comparator, which compares the input signals and the feedback signals. The output signal generated by the PD is proportional to the phase difference between the input signals and the signals generated by the internal oscillator called VCO. The output of the PD is an input to the LF. The LF is characterized with low pass filtering to attenuate highfrequency $\mathrm{AC}$ components from the PD output and provide DC controlled signal to $\mathrm{VCO}$ which acts as an integrator. The VCO generates at its output a periodic AC voltage signal provided by the LF [19].

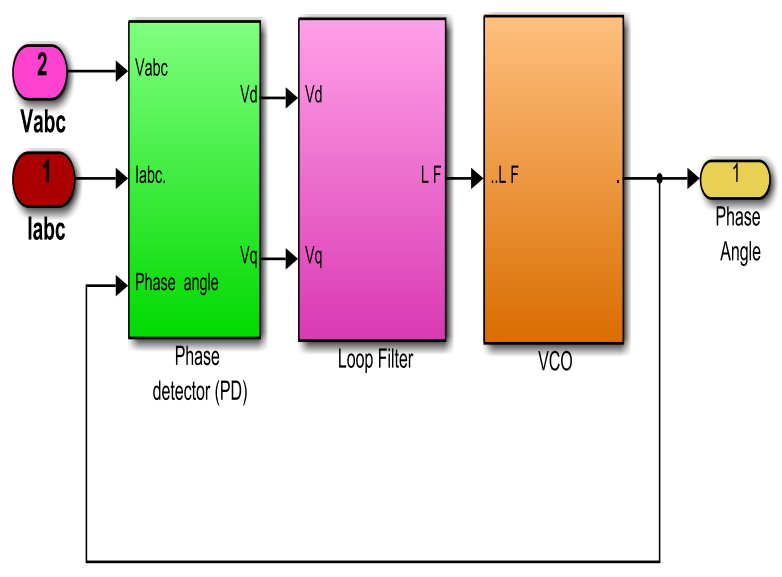

Figure 13; Subsystems of the PLL

The complete sub-system of the PLL is shown in Figure 14 which formed by masking the three blocks subsystem of PLL of figure 13.

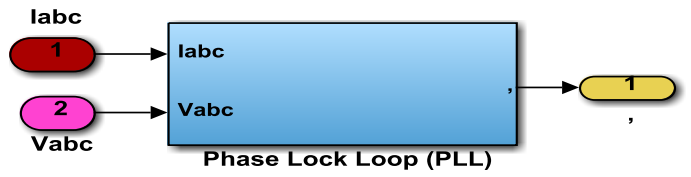

Figure 14; Subsystem of the phase locked loop (PLL)

\section{2; The complete modeled grid-connected solar system}

The model is a network of the major subsystems which comprises of the following; PV array model that saves as a DC voltage source, DC- DC boost converter model, power AC inverter model, PLL model, step up transformer, protective and measuring devices, grid source (AC), and three-phase Load. The modeling and simulation were done on individual subsystems. The PV array model was simulated, which generated $4000 \mathrm{~V}$ DC voltage as the main DC source to the boost converter. The generated $4000 \mathrm{~V}$ was then optimized by the converter to $7400 \mathrm{~V}$ DC voltage. The $7400 \mathrm{~V}$ output DC voltage of the converter model is converted to 3.phase AC voltages $\left(\mathrm{V}_{\mathrm{abc}}\right)$ by the power inverter. However, the 3-phase output AC voltage ( $\mathrm{Vabc}$ ) of the inverter is connected to 3phase step up transformer, which synchronized with the utility grid voltage of $33 \mathrm{KV}$. 


\section{3; The modeled complete photovoltaic grid connected without phase locked loop (PLL).}

The model of figure 15 was simulated without the PLL. The result obtained from the simulated grid connected solar PV array model without PLL was not quite clear as displayed by the waveforms. Based on observation, the system output is distorted by flickers. Therefore, it clearly shows that, both the solar PV array system and the utility grid are not having same characteristics.

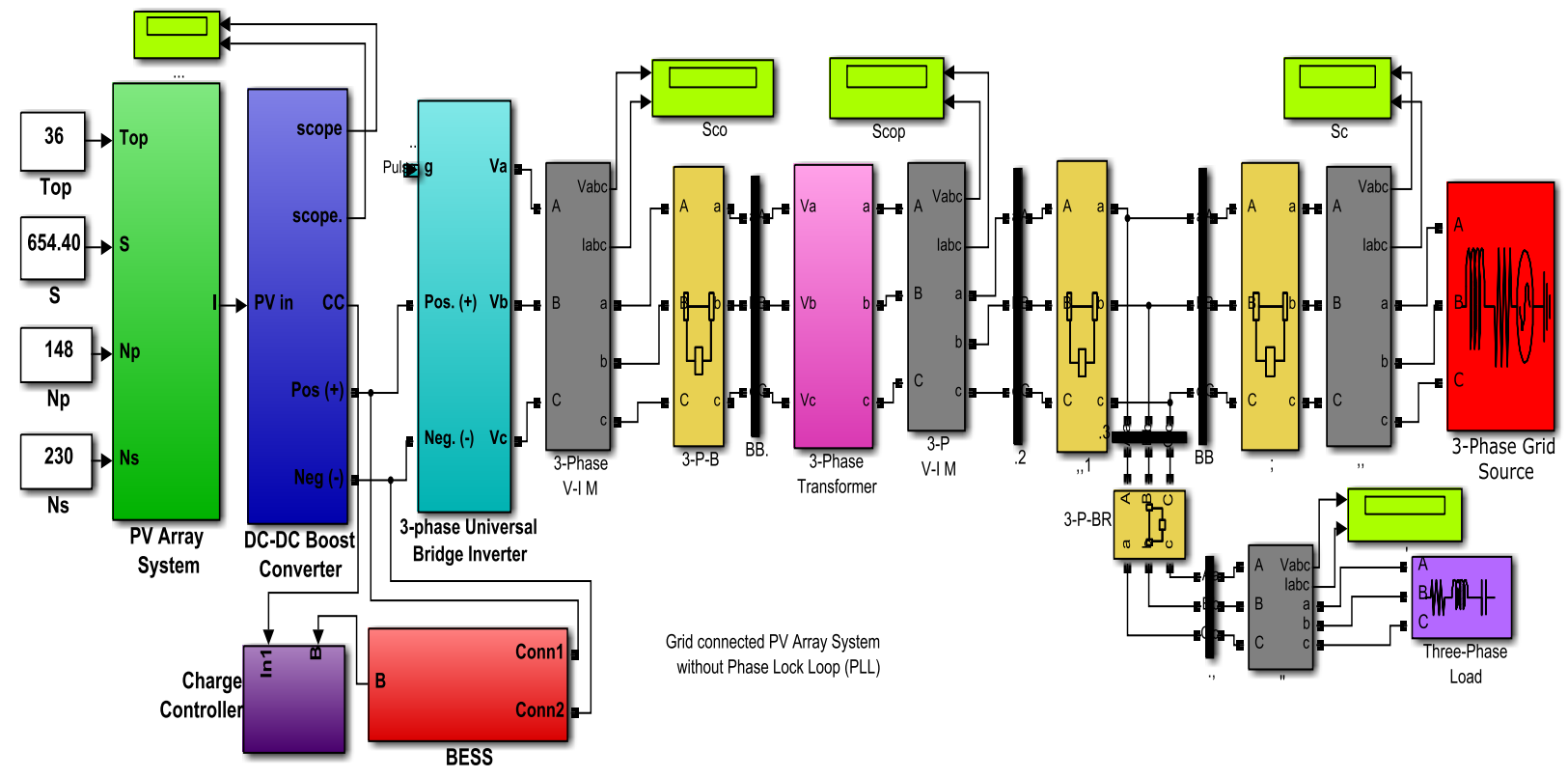

Figure 15; Simulink model of complete PV grid connected without PLL system

\section{4; The modeled grid connected PV system with PLL}

The grid-connected PV array model with PLL is shown in figure 16. Here, PLL was connected to figure 16 Model because of the distorted output of figure 15 model. The device was used to clear flickers on the lines such as phase difference, harmonics. So, synchronizing the solar PV array system with the utility grid using PLL has given a better result. The results obtained from the simulated figure 15 model shows that the model output AC voltage is $33 \mathrm{KV}$ with the same frequency, amplitude and phase angle. The result obtained indicated that the grid-connected solar PV system with battery energy storage system have succeeded in tackling the problem of power supply in the study area.

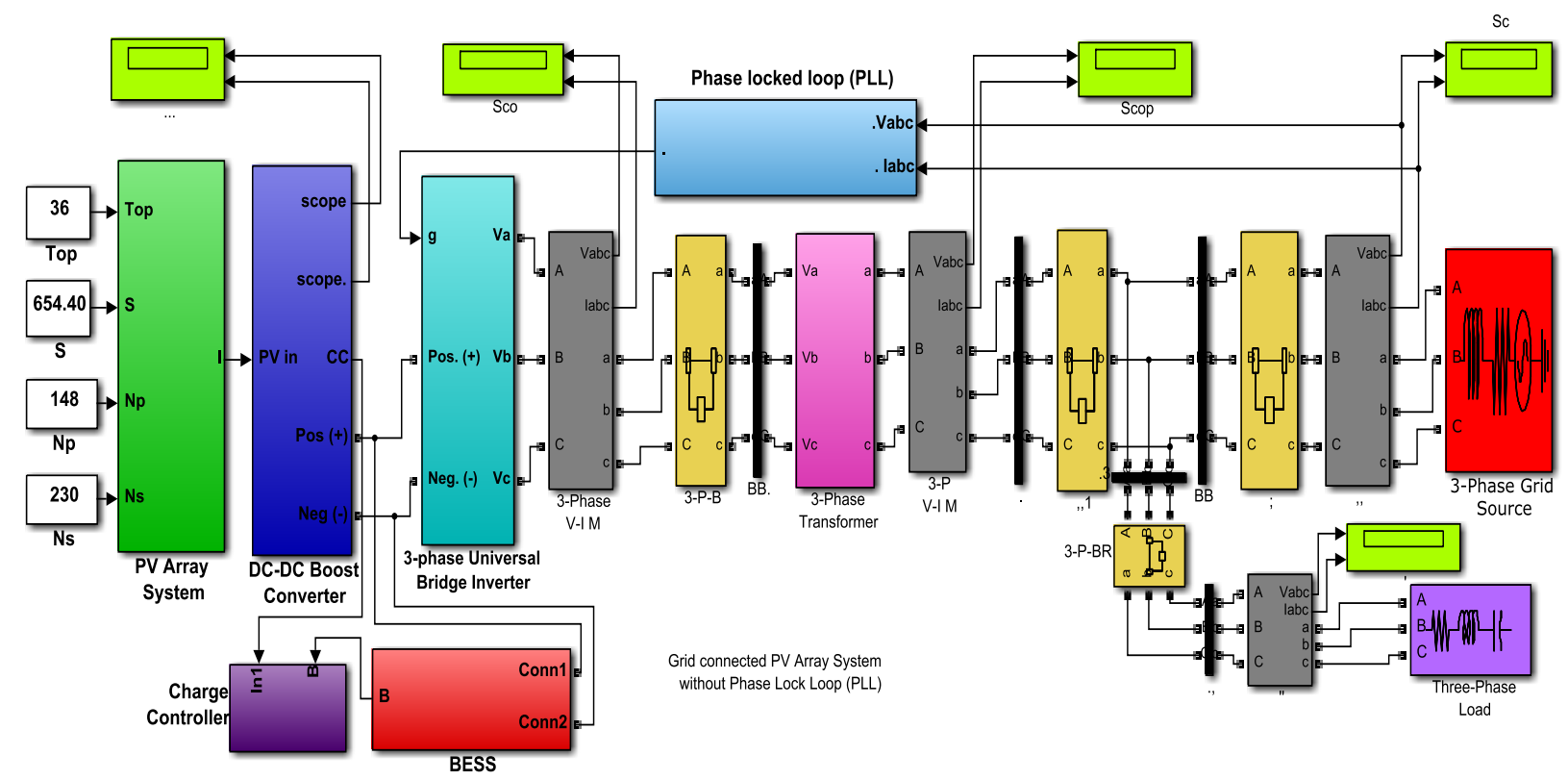

Figure 16; Simulink model of complete photovoltaic grid connected with PLL. 


\section{5; Modeled photovoltaic array system result.}

The simulated result of PV array model of figure 2 is shown in figure 17. The output of the simulated PV array model consists of DC voltage $\left(\mathrm{V}_{\mathrm{dc}}\right)$, DC current $\left(\mathrm{I}_{\mathrm{dc}}\right)$ and power $(\mathrm{P})$ waveforms displayed by the scope, as shown in figure 16. Hence, the generated DC voltage of the PV array system is $4000 \mathrm{~V}$ as displayed by the digital display system. Therefore, based on the output of the photovoltaic array the desired result has been obtained.

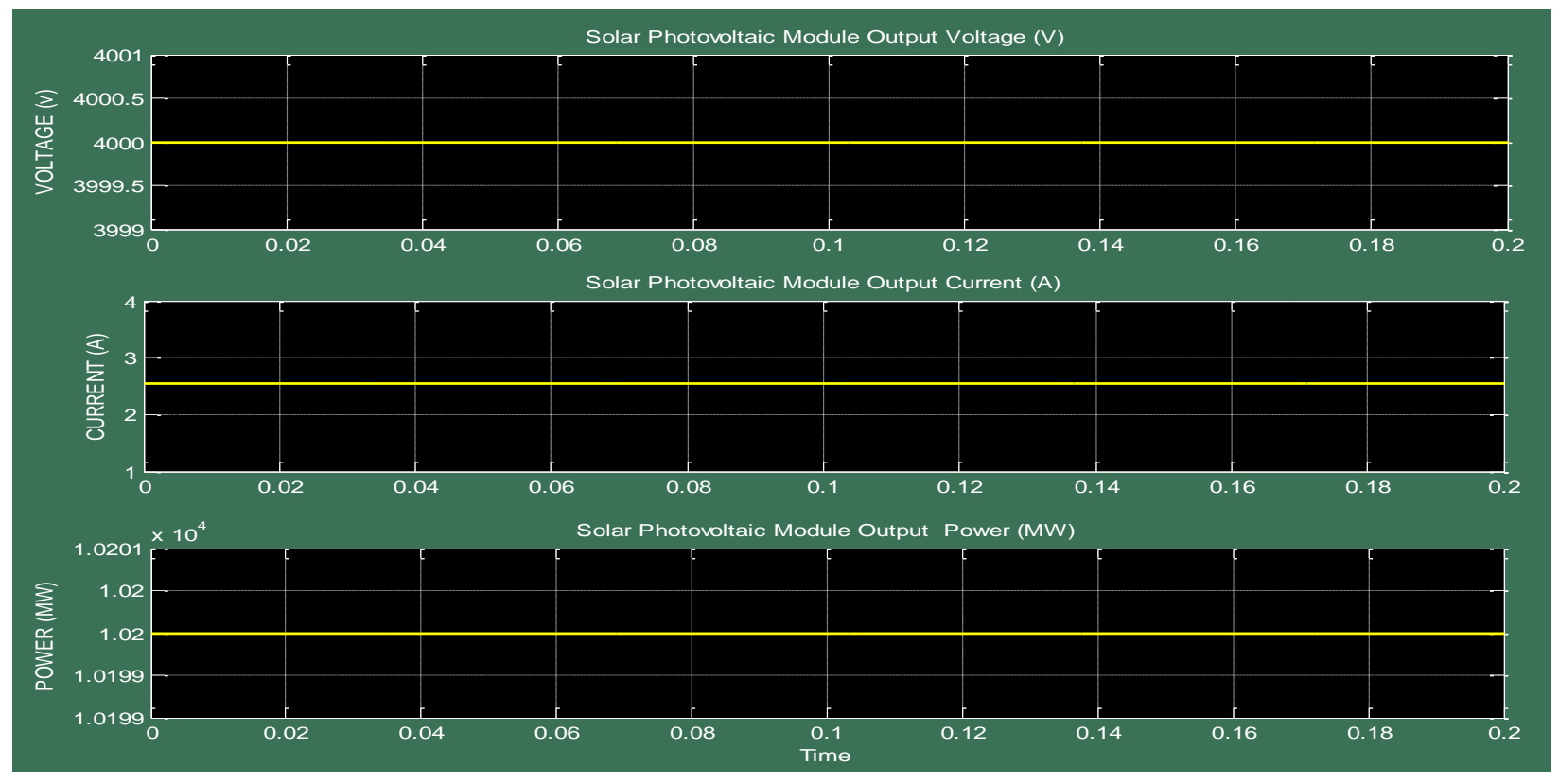

Figure 17; Solar PV array output result consists of DC-voltage, current and power.

16; The result of DC-DC boost converter.

The PV-boost converter model of figure 10 was simulated in Matlab/Simulink environment according to the standards IEC with result shown in figure 18 and 19. The scope and digital display system was connected at the output terminal of the converter for the output result analysis. The generated 4000V DC source of the PV array model was boosted to $7400 \mathrm{~V}_{\mathrm{dc}}$.

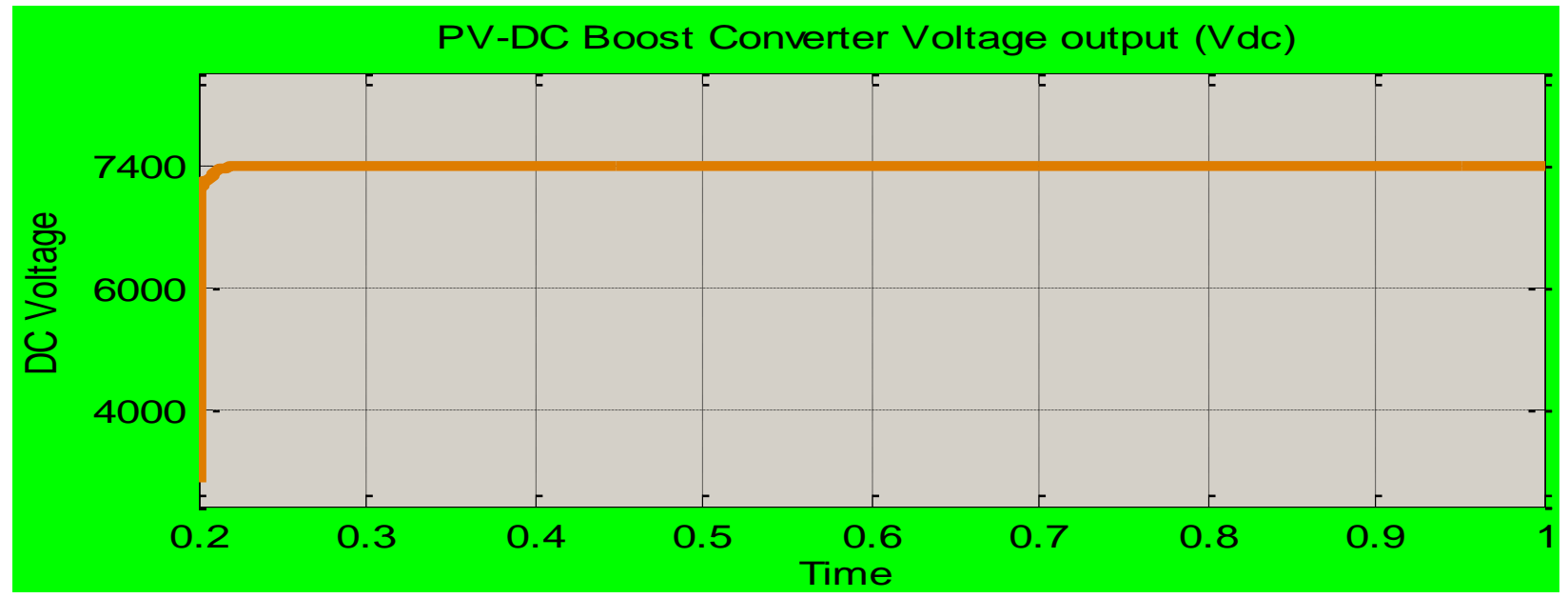

Figure 18: Photovoltaic-DC Boost Converter voltage output (Vdc) 


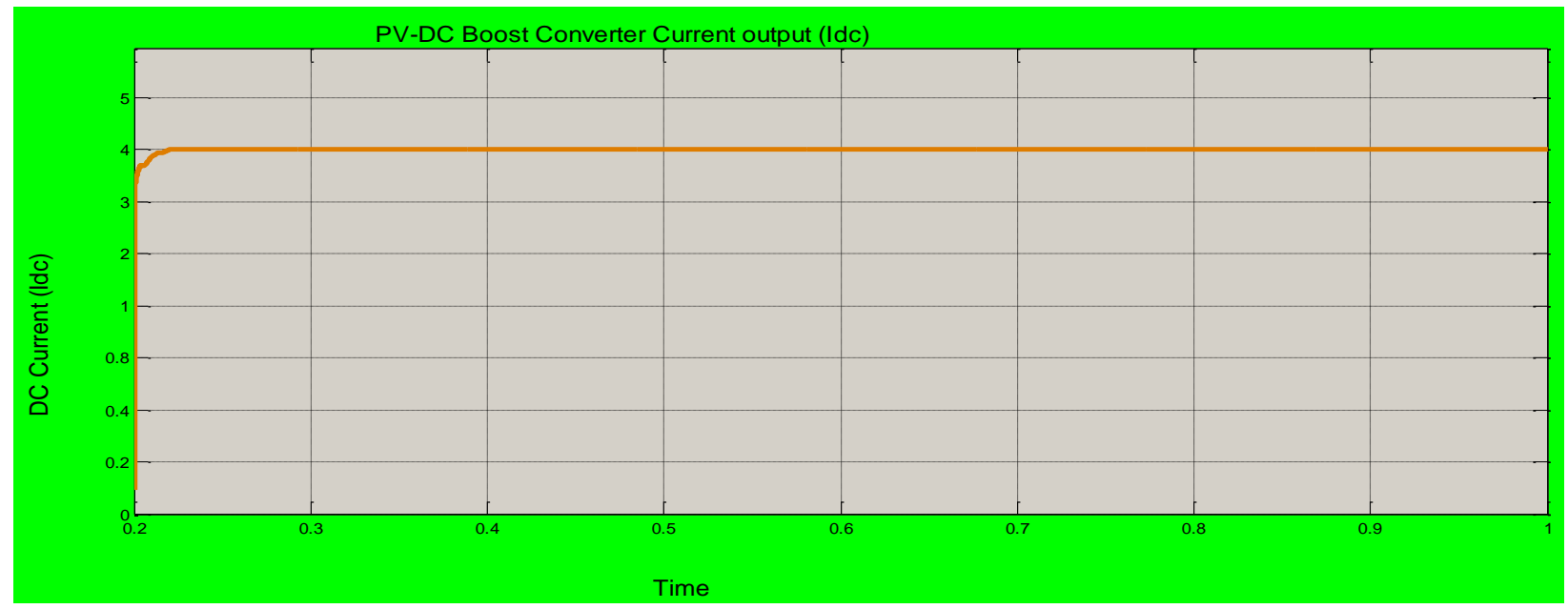

Figure 19: Photovoltaic-DC Boost Converter current output (Idc)

\section{7; Three-phase universal bridge inverter output.}

Matlab/Simulink software was used in the simulation of complete system of figure 11 , given the output result of generated three-phase AC waveforms of figure 20. The inverter does not boost or step-up the input voltage but generate the input signals into sinusoidal AC signals. In this case $\mathrm{V}_{\mathrm{abc}}$ is fed to a step-up transformer for the purpose of boosting the AC signal to a grid voltage level of $33 \mathrm{KV}$.

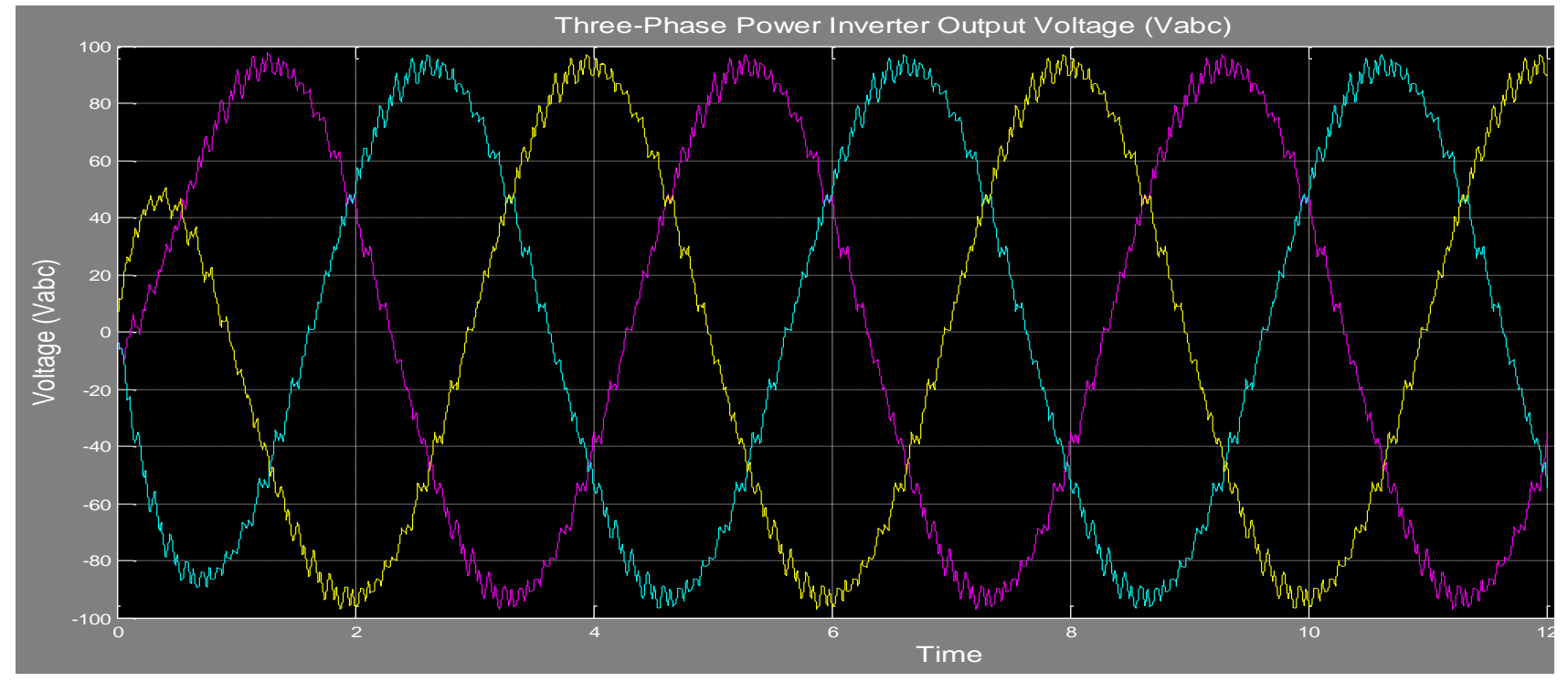

Figure 20; Three-phase universal bridge inverter result.

18; Result of complete solar PV grid system connected without PLL system;

The complete grid connected solar PV model of figure 15 was connected without control (PLL). The simulation of the modeled grid connected solar PV system of figure 15 output result is shown in figure 21. The output result clearly indicated that the synchronization was unbalanced due to the absent of PLL. Therefore, due to the poor result obtained from the system PLL is needed in the system to clear the distortions on the lines 
International Journal of Science and Engineering Applications

Volume 6 Issue 10, 2017, ISSN-2319-7560 (Online)

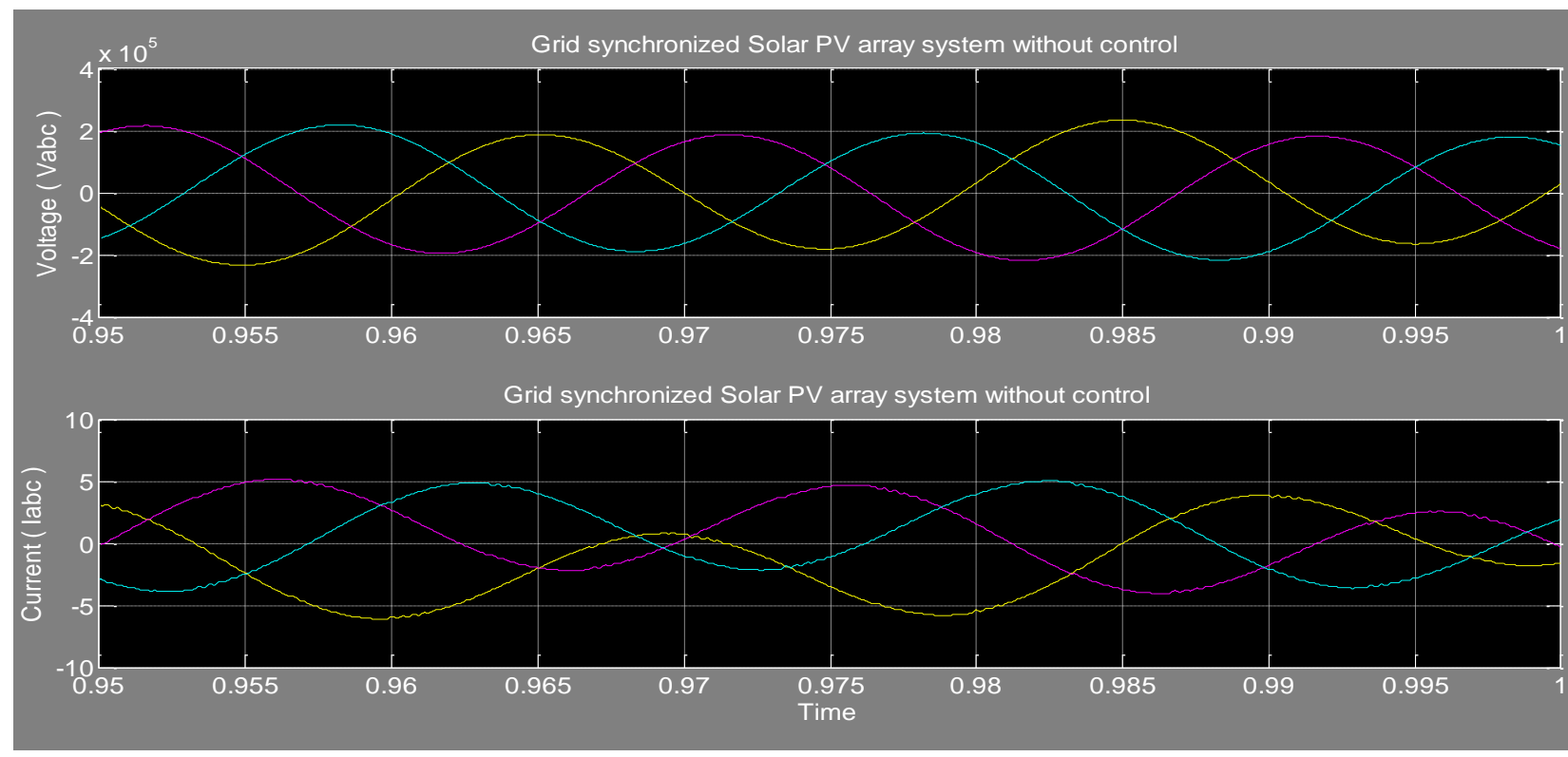

Figure 21; The result of grid synchronized Solar PV array system without a PLL system

\section{9; Result of simulated complete grid} connected solar PV system with PLL

The simulated result of the grid-connected solar PV system of figure 16 synchronized with PLL is shown in figure 22 . The introduction of the PLL into the system was due to the unbalanced output result observed from figure 20 . The selection of Phase lock loop was due to its high degree of immunity and insensitivity to disturbances, harmonics, unbalance and sags. Hence, based on the analyzed result, the generated $3.40 \mathrm{KV}$ by the PV array system injected into the utility grid network, via the three-phase step-up transformer has been satisfactory, and has complied with IEC standards.
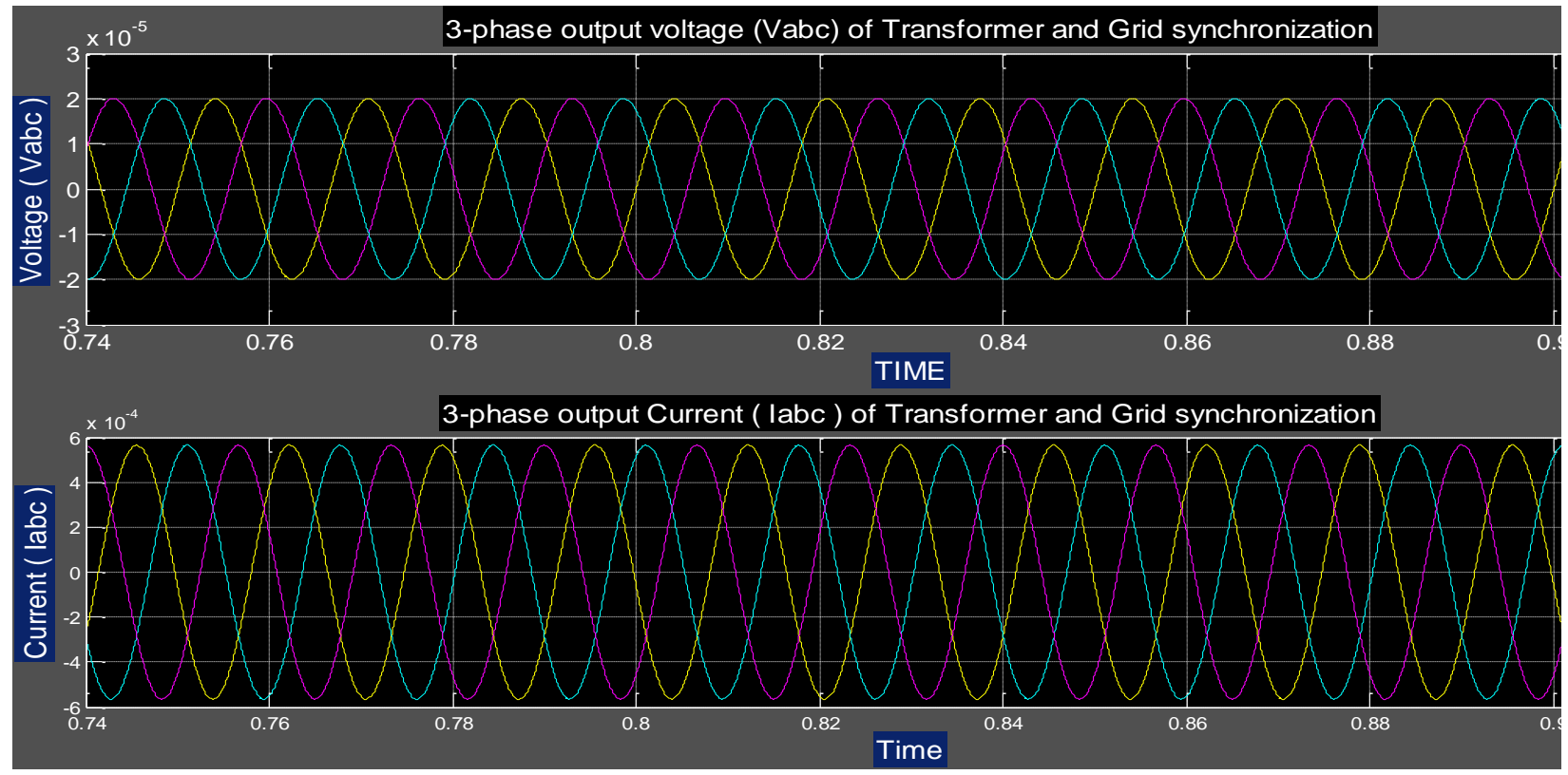

Figure 22; Solar PV array and Grid synchronization output. 


\section{0; Discussion of Results}

Solar energy sources are important part of energy supply to the utility grid Network. In this study, grid connected photovoltaic-battery energy storage system generation system was modeled and simulated in MATLAB/Simulink environment. The PV array was designed based on the standard mathematical modeling equations, and as well considering the effect of environmental weather conditions (temperature, relative humidity, rainfall, solar radiation and sunshine). The equations are put together in the form of block diagrams, and simulation is carried-out using matlab-simulink program. The photovoltaic array subsystem model was simulated using Simulink program, which generated 4000V DC voltage as the main DC source. The designed photovoltaic (PV) array system was able to supplement power shortfall of $3.40 \mathrm{MW}$ of the study area. The DC/DC boost converter was connected to photovoltaic (PV) array where the output DC voltage of the photovoltaic (PV) system was boosted by the designed boost converter to the desired output DC voltage of $7400 \mathrm{~V}$. The battery energy storage system (BESS) formed part of the system, which charged or discharge by using the DC/DC bidirectional converter to maintain the power balance between photovoltaic (PV) power generation and the load demand. Simulation results prove that the grid-connected photovoltaic-battery energy storage system (PV/BESS) provides stable and reliable power for loads or power grid during its operation modes. However, the output DC voltage of the converter was inverted to 3-phase AC voltages (Vabc) using inverter, which was synchronized with 150MVA step up transformer used to step it up to the utility grid voltage of $33 \mathrm{KV}$. The transformer's output (i.e. $33 \mathrm{KV}$ ), is the output of the entire system that is synchronized with the utility grid. The synchronizer (PLL) was connected to the system to clear disturbances on the lines. The results obtained from the simulated system are the same frequency, amplitude, and phase angle, which indicated that the designed grid-connected solar photovoltaic system have succeeded in tackling the problem of power supply in the study area.

\section{1; Conclusion}

This thesis presents a complete modeled grid-connected solar system that includes solar photovoltaic array system, DC-DC converter, battery energy storage system, phase locked loop, power inverter, step-up transformer and grid source. The objectives for this thesis have been successfully realized through the modeling, simulation and performance analysis of designed system using Matlab/Simulink tools. The designed system was based on weather condition and load demand obtained from the YEDC that gives the power supply deficit $3.40 \mathrm{MW}$ of the study area. The shortfall (3.40MW) of power supply from the grid was augmented by the designed solar photovoltaic-battery energy storage system (PV/BESS). Based on the result the solar photovoltaic array system was able to inject a total power of $3.40 \mathrm{MW}$ to the grid.

\section{REFERENCES}

[1] Ahmed, A. A. A.-R. (2013). Digital Control Techniques for Grid-Connected Inverters Electronics and Communications Engineering Department Digital Control Techniques for Grid-Connected Submitted by.
[2] Aliyu U. O. and Guda, H. A. (2015). Design of a StandAlone Photovoltaic System for a Residence in Bauchi, 5(1), 34-44.

[3] Ani, V. A. (2016). Design of a Reliable Hybrid (PVDiesel) Power System with Energy Storage in Batteries for Remote Residential Home.

[4] Bellia, H. (2015). A detailed modeling of photovoltaic module using matlab a detailed modeling of photovoltaic module using matlab. nriag journal of astronomy and geophysics, (june 2014). http://doi.org/ 10.1016/j.nrjag. 2014. 04.001

[5] Chen, H., Chen, P., Chang, L., \& Bai, W. (2013). StandAlone Hybrid Generation System Based on Renewable Energy. http://doi.org/10.7763 /IJESD. 2013.V4.405

[6] DEBASHIS DAS, S. K. P. (2011). Modeling and simulation of pv array with boost converter: an open loop study modeling and simulation of pv array with boost converter : an open loop study.

[7] Duka, I. \& Noble, C. (2011). High frequency DC-DC boost converter. retrieved from https:// www. wpi.edu / pubs/ e project/ available, e-project 042711-220800 unrestricted high frequency DCDC boost converter mqp final duka noble.pdf Dunlop, J. P. (n.d.). Batteries and Charge Control in Stand-Alone Photovoltaic Systems Batteries and Charge Control in Stand-Alone Photovoltaic Systems Fundamentals and Application.

[8] Engineering, A., Ahmad, Z., \& Singh, S. N. (2013). Modeling and Control of Grid Connected Photovoltaic System- A Review, 3(3), 40-49.

[9] GEBREEL, A. A. G. M. (2011). Simulation and implementation of two- level and three-level inverters by matlab and rt-lab.

[10] Gupta, A., \& Garg, P. (2013). Grid integrated solar photovoltaic system using multi level inverter, 3952-3960.

[11] Guyo, K. G., \& A. (2013). Design of a Grid Connected Photovoltaic System for Enhancement of Electrical Power Supply in Kenya : A Case Study of Nairobi Embakasi Kidegho Gideon Guyo A thesis submitted in partial fulfillment for the degree of Master of Science in ( Electrical Enginee. Photovoltaic System for Enhancement of Electrical Power Supply.

[12] Henry Massawe S, P. U. (2015). Modeling and Simulation of a PV System using DC-DC Converter School of Electrical Engineering Aparna K P , Priya R , Sindhu Suryanarayanan, 1(2), 9-16.

[13] Hosseini, E. (2015). Modeling and simulation of choppers switching via matlab / simulink, 12(1), $10-17$. 
[14] Khamis, A., Shareef, H., \& Ayob, A. (2011). Modeling and simulation of a microgrid testbed using photovoltaic and battery based power generation microgrid system modeling photovoltaic ( pv ) model, 2(11), 658-666.

[15] Kircicek, Y., Aktas, A., \& Ucar, M. (2014). Modeling and Analysis of a Battery Energy Storage System Supplied from Photovoltaic Power Source, 1-13.

[16] Limkumnerd, S., \& Eungdamrong, D. (2007). Mathematical models and simulations of phase noise in phase-locked loops, (February 2007).

[17] Naidu, V. V, \& Mohan, T. M. (2013). Modeling and simulation of photovoltaic system, (6), 2-7.

[18] Natsheh, E. M., Albarbar, A., \& Yazdani, J. (2009). Modeling and Control for Smart Grid Integration of Solar / Wind Energy Conversion System. Modeling and Control for Smart Grid Integration of Solar/Wind Energy Conversion System, 1-8.

[19] Rafal, K., Jasinski, M., \& Kazmierkowski, M. P. (2011). Grid synchronization and symmetrical components extraction with PLL algorithm for grid connected power electronic converters - a review, 59(4). http://doi.org/10.2478/v10175-011-0060-8

[20] Rout, S. (2015). Mathematical modelling of grid connected photovoltaic system using matlab / simulink and hardware implementation, (etcc), 611 . 